\title{
Public councils in Kazakhstan: a case of emergent participative democracy?
}

\section{Colin Knox \& Saltanat Janenova}

To cite this article: Colin Knox \& Saltanat Janenova (2018) Public councils in Kazakhstan: a case of emergent participative democracy?, Central Asian Survey, 37:2, 305-321, DOI: 10.1080/02634937.2017.1410467

To link to this article: https://doi.org/10.1080/02634937.2017.1410467

曲 Published online: 20 Dec 2017.

Submit your article to this journal

Џlll Article views: 229

View Crossmark data \lceil 


\section{Public councils in Kazakhstan: a case of emergent participative democracy?}

\section{Colin Knox and Saltanat Janenova}

Graduate School of Public Policy, Nazarbayev University, Astana, Kazakhstan

\begin{abstract}
As Kazakhstan aims to become one of the top 30 developed countries by 2050, it is increasingly turning to ways which will improve its governance, one of which is greater participation by its citizens in the decision-making processes of state agencies. A new initiative aimed at doing just that, the establishment of public councils, received legal backing in January 2016. The aim of public councils is to 'strengthen democracy and the quality and responsiveness of public polices' through the 'public expression of matters of concern to Kazakh citizens'. This article offers a formative evaluation of the role performed by public councils and questions the extent to which they have achieved this aim. It draws on primary data from public officials, non-governmental organizations, ministries, and non-participant observation of public councils in Kazakhstan. It finds limited evidence of their effectiveness to date.
\end{abstract}

\section{KEYWORDS}

Participative democracy; public councils; Kazakhstan; citizen engagement

\section{Introduction}

Citizen participation and engagement in Central Asian countries is still an idea in its infancy. The Bertelsmann Transformation Index (2016) lists four of the five central Asian countries (Kazakhstan, Tajikistan, Turkmenistan and Uzbekistan) as 'hard-line autocracies', while Kyrgyzstan is categorized as a 'highly defective democracy'. Central Asia's postSoviet legacy suggests highly centralized systems with limited involvement of citizens in government decision-making processes. Historically, citizens' voices have been unheard, unsolicited, or ignored. Mechanisms such as civil society organizations, which could mobilize citizens' inputs, remain weak or largely controlled by governments in the region (Kabdiyeva 2015; Knox and Yessimova 2015). Citizen participation is more closely associated with deliberative processes in democratic polities aimed at incorporating the views of the public who have a stake in society. With this comes the notion that democracies have an ethical imperative to engage with citizens and, in so doing, promote a strong conception of citizenship where people possess civic and political knowledge and, as a result, a greater sense of empowerment and agency (Mouffe 1992; Thompson and Tapscott 2010; Michels 2011; Fung 2015). Developed countries list multiple benefits arising from citizen engagement: it improves policy development; it is a way for government to check the health of the relationship with citizens; it reveals how 
government and citizens can work closely together; it gives early notice of emerging issues; it provides opportunities for a diversity of voices to be heard; it enables citizens to identify policy priorities; and it fosters a sense of mutuality and empowerment (Holmes 2011).

Yet there are also significant benefits from greater inclusiveness and participation in developing countries. This can involve citizens exercising their voice against injustices and discrimination and, more generally, contributing to an improvement in their wellbeing and quality of life. Engagement can also address a range of development and governance goals, including reducing corruption, improving public services and increasing social capital (Sen 1999; UNDP 2016a). Gaventa and Barrett (2010) conducted a metaanalysis using 100 research case studies of four types of citizen engagement in 20 countries to establish the extent to which it contributed to improved governance and development outcomes. ${ }^{1}$ The overall finding was that citizen engagement has 'positive effects across these outcome types, though in each category there are also examples of negative outcomes of citizen participation' (3). Importantly, political context affected outcomes in a number of ways. First, the weakest and most fragile democracies showed the highest positive outcomes related to social inclusion and cohesion; and second, engagement can result in positive differences even in the least democratic states. As Gaventa and Barrett conclude: 'It may be in those countries where there have been fewest opportunities for engagement that the most difference can be made' (54). This is an important finding for the policy intervention (public councils in Kazakhstan) outlined in this article. A useful benchmark study by Kasymova (2017) of citizen engagement in public budgets in Kyrgyzstan found similar barriers: lack of democratic administration; limited trust in government institutions; poor implementation of laws; and limited state capacity. She concluded that 'any participatory initiative that is affiliated with government is viewed with skepticism' (384).

There are several typologies or schema in the literature which offer researchers ways to structure how we think about citizen engagement and participation. The seminal work of Sherry Arnstein (1969), for example, and her ladder of participation is a case in point. The bottom rungs of the ladder describe non-participation as manipulation and therapy, moving upwards through tokenistic engagement (informing, consultation and placation), to the highest levels of citizen power involving partnership, delegated power and citizen control. Ekman and Amnå $(2012,292)$ also developed a typology of civic engagement, which they describe as 'latent political participation'. Loeffler and Martin $(2016,302$, citing Tritter and McCallum 2006) argue that Arnstein's ladder of participation implies a normative hierarchy, whereas they contend that 'what matters most is that the form of citizen engagement is fit for purpose'. They offer a typology which distinguishes between different intensities of citizen engagement: information, a one-way relationship between government and citizens; consultation, a two-way dialogue where citizens are given a voice; public participation in decision-making; and co-production of public services and outcomes, the most demanding form of engagement.

One form of intensive engagement in Kazakhstan is the recent introduction of public councils, which represent a radical and innovative bottom-up participation mechanism. Because the were introduced fairly recently, no research exists on how effective they are, either as a mechanism for public engagement or to hold public bodies to account in Kazakhstan. This article offers a formative assessment of the work of public councils 
through qualitative research with serving civil society members and state agencies for which they perform an advisory and consultative role. The research question addressed is whether public councils offer an effective citizen engagement model for the citizens of Kazakhstan. As Kazakhstan is a leading country in the Central Asian region, there may also be lessons for neighbouring countries, whose record on openness and freedom is very poor. ${ }^{2}$

\section{Wider civil society}

Public councils exist within a wider civil society context, which is important in understanding their origins and operating environment. The literature on civil society in Central Asia, and specifically on Kazakhstan, is still fairly limited (Babajanian, Freizer, and Stevens 2005). At the level of Central Asia, Ziegler's $(2010,2015)$ research is the most comprehensive. He explains the two-dimensional nature of the problem with civil society mobilization and activism. On the one hand, government officials display a 'Soviet-style mindset contemptuous of public opinion'; but on the other, this is reinforced by the presence of inactive communities, which need to 'shift from the kollektiv mentality of the communist era towards a more personal sense of responsibility for governance' (Ziegler 2010, 808, 814). In an overview of the relationships between Central Asian states and civil society, Ziegler concludes:

The Central Asian states could be said to exhibit elements of authoritarian deliberation on the Chinese governance model. In this system, limited expression is tolerated by the authorities and utilized for guidance in forming public policy, while avoiding genuine political pluralism.

In a wider context, however, there is an interesting literature on the role civil society plays in authoritarian states such as those of Central Asia. Scholars in this area have questioned whether a strong civil society is a necessary condition for transitioning from authoritarian regimes to fully functioning democracies. Daucé (2014), for example, drawing on a case study of the Moscow Helsinki Human Rights Group, concluded that Russian authorities adopted a hybrid approach where they restrained activists and, at the same time, cooperated with NGOs through a grant-making policy. She concluded that this approach resulted in reduced violence against civil society activists. In short, according to these scholars (Cavatorta and Durac 2011; Rivetti and Cavatorta 2013) there are circumstances where authoritarian regimes and elements of civil society expression can effectively coexist. Ziegler's recent research suggests that the context in which civil society exists is unlikely to change any time soon. Central Asia has been influenced indirectly by Russia's 'authoritarian diffusion', which 'strengthens resistance to Western civil society promotion efforts' $(2016,550)$. A combination of limitations on foreign funding of NGOs and Western democracy promotion fatigue will, he argues, lead to the persistence of authoritarianism in Central Asia.

With specific reference to Kazakhstan, Soltys' $(2014,15)$ work on environmental groups paints a fairly sanguine view of the role they play, claiming that President Nazarbayev has instructed his officials to be 'more amenable to civic initiatives than these officials would have been otherwise'. Nezhina and Ibrayeva (2013) argued that estimates of civil society groups operating in Kazakhstan are overstated because many registered NGOs are 
dormant or inactive: there could be as few as 800 groups in the whole country, and those civil society groups 'inspired by Western donors are currently ineffective in Kazakhstan' (356). In a similar vein, Kazkenov and Ziegler $(2015,209,217)$ argue that 'civic activism independent of government direction or support remains an alien concept' in Kazakhstan, which state officials find preferable. The role of civil society there is to be a 'pliant supporter of government policies, rather than a critic or watchdog'. Charman and Assangaziyev (2015), on the other hand, see a valuable role for NGOs in Kazakhstan to hold government to account for improving public services delivery. They suggest a stronger advocacy role than currently exists. Greater participation by civil society groups would 'create greater incentives and a more conducive environment for reaching the levels of quality in public services delivery that the authorities have set out to achieve', but NGOs lack the 'participation, organization and critical mass' to make this happen in Kazakhstan (171). Public councils must therefore be seen within the context of a weak civil society infrastructure in Kazakhstan.

\section{Kazakhstan: political and social context}

Kazakhstan is emerging as the most dynamic economic and political actor in Central Asia since its independence from the Soviet Union in 1991. It is the ninth-largest country in the world, with a territory equal to that of Western Europe, but with one of the lowest population densities. Kazakhstan has rich natural resources, particularly oil and gas reserves (the country ranks 12th in the world in terms of oil reserves and 19th for natural gas reserves), and attracts an increasing flow of foreign direct investments. As a result of its access to oil resources, Kazakhstan has moved from a lower-middle-income country to an uppermiddle-income country in two decades. More recently, however, there has been an economic slowdown; real GDP growth dropped from 4.1\% in 2014 to $1 \%$ in 2016 as the economy contracted. The move to a floating exchange-rate regime in August 2015 led to steep depreciation of the Kazakhstani tenge (KZT) and a sharp increase in inflation, eroding wages and consumer purchasing power (World Bank 2016). In socio-economic terms, Kazakhstan is ranked 56th out of 188 countries in the Human Development Index, which measures key dimensions of health, education and income (UNDP 2016b). In this regard, Kazakhstanis have a life expectancy at birth of 69.6 years; 15 years of expected schooling; and a gross national income per capita of USD 2093 (purchasing power parity). Politically, the country is a presidential republic, with a bicameral parliamentary system of government, which is dominated by the Nur Otan (Radiant Fatherland) Party, headed by the president, and with limited political opposition. Recently (March 2017) there has been an attempt through constitutional reforms to strengthen the role of parliament and the government by transferring some powers of the president, and to modernize the judicial system. Still, the Freedom House Report $(2017,2)$ describes Kazakhstan as a 'consolidated authoritarian regime'. One consequence of this for civil society has been a tightening of control on their daily operations. All funding to NGOs must be channelled through a single state source, which has a veto on which bodies receive funding and for which purposes. Increasingly cumbersome rules are also involved in receiving funding from foreign NGOs, which are viewed with suspicion as having wider ulterior political motives (Lillis 2017, 4). 


\section{Citizen engagement in Central Asia}

While the barriers to effective citizen engagement and weak civil society described above are evident in Central Asian countries, Kazakhstan is making attempts, encouraged by international organizations and a motivation to gain respectability on the world stage, to become a more open and inclusive country. Kazakhstan has embraced public management reforms, central to which were ideas of citizen involvement and a customer orientation (Manning 2001; Knox 2008; Emrich-Bakenova 2009; Amagoh 2011; Bhuiyan and Amagoh 2011; Monobayeva and Howard 2015). Yet transferring the concept and practice of citizen engagement to developing countries is problematic.

If, for example, one looks at the scale of this problem in the Central Asia region, the magnitude of the task becomes clear. Kyrgyzstan is the best example among countries in the region and has witnessed an expansion of civil society and the growth of an independent media. While the growth of NGOs and associations is evident, most are located in the urban areas of Bishkek and Osh, and many depend on foreign funding. Tajikistan has also seen growth in the number and range of NGOs, but their role is one of service providers, with few examples where they have mobilized communities to advocate social change. There has been a flurry of activity from youth and student groups, largely concentrated in Dushanbe and Khujand, but this has been fleeting, with limited lasting impact. Uzbekistan and Turkmenistan are largely unreceptive to civil society representation. In both countries, the role of the state is pervasive and their populations historically inactive and subdued. As a result, any attempt at grass-roots mobilization is viewed by state authorities as potentially destabilizing, bordering on the seditious, in view of the 'colour' revolutions in Georgia, Ukraine and Kyrgyzstan. Examples of repression in Turkmenistan include exclusion of civil society actors from the political process and a law which prohibits NGOs from receiving funds from international donors (Bertelsmann 2016). In summary, Central Asia has a history of limited civil society mobilization and engagement, exemplified by problems associated with repression of civil society's voice in countries largely without an independent media; historically inactive communities; limitations placed by government on NGO registration and freedom to operate; dependence on foreign funding; and relegation of NGOs to a role as service providers, masquerading as evidence of strong civil society. Similar issues were identified by Buxton $(2009,55)$ when he argued that problems facing Central Asia's NGOs included threatened or actual restrictions in the new post-colour-revolutions political context; the unfinished business of multi-party democracy building; and imperfect media and justice systems.

To locate the experiment with public councils in Kazakhstan alongside other Central Asian countries, we set out key statistics in Table 1. Kazakhstan has very little civil society participation, and the traditions of civil society are very weak. It is therefore starting from a very low base with new forms of participation.

\section{Open government in Kazakhstan}

A weak civil society with limited social capacity would suggest a repressive environment in which the voice of the citizen is significantly curtailed or unwelcome. The other side of this coin is that, given Kazakhstan's Soviet roots, there is a degree of passivity amongst its people. The idea that the state is pervasive, paternalistic and top-down does not 
Table 1. Civil society statistics in Central Asia.

\begin{tabular}{|c|c|c|c|c|c|c|}
\hline Country & $\begin{array}{c}\text { Human } \\
\text { Development } \\
\text { Index (out of } 187 \\
\text { countries) }\end{array}$ & $\begin{array}{l}\text { Civil society } \\
\text { participation } \\
(1-10)^{\mathrm{a}}\end{array}$ & $\begin{array}{c}\text { Civil society } \\
\text { traditions - level } \\
\text { of difficulty (1- } \\
10)^{\mathrm{b}}\end{array}$ & $\begin{array}{c}\text { Democratic } \\
\text { status }(1-10)^{c}\end{array}$ & Classification & $\begin{array}{l}\text { GDP per } \\
\text { capita } \\
\text { (USD) }\end{array}$ \\
\hline Kyrgyzstan & 125 & 6 & 5 & 6 & $\begin{array}{l}\text { Highly } \\
\text { defective } \\
\text { democracy }\end{array}$ & $3,322.2$ \\
\hline Tajikistan & 133 & 4 & 9 & 3.6 & $\begin{array}{l}\text { Hard-line } \\
\text { autocracy }\end{array}$ & $2,690.8$ \\
\hline Turkmenistan & 103 & 1 & 10 & 2.9 & $\begin{array}{l}\text { Hard-line } \\
\text { autocracy }\end{array}$ & $15,473.6$ \\
\hline Uzbekistan & 116 & 1 & 9 & 3.0 & $\begin{array}{l}\text { Hard-line } \\
\text { autocracy }\end{array}$ & $5,575.9$ \\
\hline Kazakhstan & 70 & 2 & 8 & 3.7 & $\begin{array}{l}\text { Hard-line } \\
\text { autocracy }\end{array}$ & $24,204.7$ \\
\hline
\end{tabular}

${ }^{a}$ This scale is devised in response to the question, 'To what extent does the political leadership enable the participation of civil society in the political process?' Participation here includes agenda setting; policy formulation; deliberation and decision-making; policy implementation; and performance monitoring. A score of $10=$ important role for civil society. A score of 1 = suppressed civil society.

'This scale is devised in response to the question, 'To what extent are there traditions of civil society?' Traditions here include long-term presence of public civic engagement; civic culture of participation in public life; numerous and active civic associations; and social trust (social capital). A score of $10=$ traditions of civil society are very weak. A score of $1=$ traditions of civil society are very strong.

'Measures stateness; political participation; rule of law; stability of democratic institutions; and political and social integration.

Source: Compiled from Bertelsmann Stiftung's Transformation Index (2016).

encourage engagement and grass-roots attempts to influence government laws and policies. Moreover, a stronger voice for citizens could be seen as threatening the established political legitimacy and societal stability, as exemplified by a recent clamp-down on the growth of social media critical of government policies and public services. These measures include penalties for journalists who criticize government bodies; registration requirements for bloggers (to tackle anonymous negative commentary on the state); and a household registration process for citizens who remain more than three months in one location in Kazakhstan, ostensibly imposed as a security measure. The underlying unofficial concern is that an open society will expose public officials engaging in petty or grand corruption. Perhaps more routinely, public participation would reveal poor levels of public services and either limited capacity or unwillingness on the part of government officials to respond to the need for change.

But is this changing? There have been some tentative signs, perhaps not in a radical way, of the public wanting to be more active and involved. Sitting alongside this bottom-up momentum for change is external pressure from international organizations, such as the OECD, to reform, if Kazakhstan wants to join its ranks and become one of the top 30 developed countries. In a fairly recent report on Kazakhstan, the OECD $(2015,190)$ noted:

Citizens expect openness and inclusiveness from government in several areas. One is through a systemic, comprehensive approach to institutionalising a two-way communication with stakeholders, whereby relevant, useable information is provided, and interaction is fostered as a means to improve transparency, accountability and engagement.

In fact Kazakhstan has made some important tentative steps towards open government. A pillar of its strategic planning process, the Plan of the Nation, 100 Concrete Steps (2015), is 
the creation of a transparent and accountable state. Pledges in the plan include: the introduction of open government; annual public statements of state agencies on their achievements; much improved web access to statistical data of public bodies; and empowering citizens to participate in the decision-making process through the development of local governance. In 2015, the Kazakhstan government approved a new Access to Information Law and a Public Councils Law. Like many laws in Kazakhstan, the problem is in the implementation stages. An early assessment of Access to Information legislation finds a lack of clarity on the exceptions in the law for denying access to information; specific criteria for which information is deemed for 'official use only'; how public officials classify or declassify information; and the types of violations and sanctions. No one has been named as responsible for access to information in state agencies. On the other hand, positive developments include the successful implementation of e-government services, which have made state-citizen interactions much more transparent and reduced corruption opportunities, and a Government for Citizens initiative which adapts Canadian and Australian models of public service centres to Kazakhstan (Janenova and Kim 2016).

In a review of open government in Kazakhstan, the $\operatorname{OECD}(2017,122)$ noted that while Kazakhstan's access to information is an important first step towards greater transparency and accountability, the second step must be to increase the level of citizen engagement through consultation: 'In contrast to the initial step of disclosure of public information, this second step constitutes a two-way relationship in which citizens and government representatives work together to improve policies in the country'. To advance the consultation process, Kazakhstan has created public councils as a mechanism for government-citizen engagement.

\section{Public councils}

Public councils are not new; they have been established in other developing countries in the former Soviet Union, sub-Saharan Africa, Latin America and south Asian countries (OECD 2017). They were introduced in Kazakhstan under the legislation About Public Councils No. 383-V SAM, 2015, and came into existence 1 January 2016 as autonomous and independent bodies established for the purpose of holding state organizations at all levels to account through the broad participation of NGOs and citizens in the decision-making process. The involvement of the NGO sector in a consultative capacity with government bodies has some limited history in Kazakhstan through a framework called the Development of Civil Society in Kazakhstan (2006-11). There are 229 active public councils in place at the time of writing (June 2017) with some 4000 members across Kazakhstan (population 18 million).

Specifically, under the law, the purpose of public councils is 'the public expression of civil society views on matters of public concern' (Article 3). The role of public councils is advisory and consultative only, and they have been set up by all ministries and central executive bodies, except those which are part of the government of the Republic of Kazakhstan (e.g., Constitutional Court, Ministry of Defence, Prime Minister's Office). Public councils have also been established for local public administration bodies (akimats [local authorities], rural councils, and village bodies). Formally, public councils now exercise a role in the public oversight and transparency of central and executive bodies and local self-government in Kazakhstan. They are allowed to do this in several ways: 
- Discussion of the strategic plans, programmes and budgets of state and local government bodies;

- Checking their performance against target indicators;

- Assessing the implementation of funded programmes;

- Development and discussion of draft laws and regulations concerning the rights, freedoms and responsibilities of citizens;

- Improving the governance and transparency of state bodies, including adherence to professional ethics; and

- Development and introduction of the state bodies' proposals on improving the legislation of the Republic of Kazakhstan.

The law introducing public councils states that their overall purpose is to improve the efficiency, openness and transparency of state bodies and local self-government. They aim to do this by protecting the public interest, raising public confidence in the activities of the state, and involving the public in the process of combating corruption. This is a hugely ambitious but potentially pioneering agenda for change.

Public councils comprise not less than two-thirds representatives from NGOs and members of the public, and one-third state or local government representatives. The former is based on membership proposals from non-profit organizations and citizens 'on a competitive basis' using local media and the Internet for recruitment purposes, and the latter is determined by the head of the state or local government body concerned. There are essentially three mechanisms that public councils can utilize to hold state bodies to account. They can monitor, hold a public hearing on, or conduct a public examination of public bodies to assess whether their strategic plans and budgets, implementation of state programmes, application of Kazakhstan legislation, or provision of public services hurt public interests. To conduct their work, public councils must be given access to information about the object of their public scrutiny and be offered cooperation by state bodies. In addition, they can seek submissions from individuals or citizens' groups. Public bodies, in turn, must listen and offer a 'reasonable response' to the recommendations of public councils within 10 working days, signed by the head of the relevant state body. Public councils must inform the public of their work at least twice a year through the media and/or Internet, and publish an annual report on the relevant website of the public body they are overseeing.

\section{Formative assessment}

Although public councils are still at the early stages of development in Kazakhstan, what has been the experience of participants in their work to date? To address this question the authors conducted a series of research activities and data gathering. Two workshops, conducted in Russian, were held between April and June 2017 with 59 representatives from the ministry responsible for the public councils (the Ministry of Religion and Civil Society Affairs), Mazhilis (lower house of bicameral Parliament), NGOs (Civil Alliance of Kazakhstan and Zertteu Research Institute) and representatives of public councils. The public councils' participants at the workshops included those with a consultative role across several ministries (Internal Affairs, Education and Science, Investment and Development, Defence and Aerospace Industry, Agriculture, Justice, Labour and Social Protection, 
Defence, Civil Service Affairs and Anti-Corruption, Healthcare, and Finance). The workshops were held in Astana, the capital city and government headquarters of Kazakhstan. They therefore attracted a large number of central state agencies as opposed to local bodies (maslikhats [local parliaments] and akimats). Follow-up one-on-one interviews with NGO members (10) and public officials (5) were conducted for public councils not represented at the workshops. The researchers also engaged in non-participant observation of public council meetings in four other regions in Kazakhstan: Shymkent, Kostanay, Oskemen and Oral.

The criteria used to conduct a formative evaluation of public councils as a participatory mechanism were drawn from a framework devised by Rowe and Frewer (2000). A formative evaluation is an early-stage assessment of the work of councils which is aimed at helping them 'take-stock' of their work-in-progress. This is different from a summative evaluation, which takes place at the end of an intervention. Rowe and Frewer suggest the need to consider which aspects of the engagement process are desirable and then to measure the presence and quality of these process elements. They therefore divide evaluation criteria into two types: acceptance criteria, which are those features that make public councils (in this case) acceptable to the wider public; and process criteria, which refer to features of the process that make them effective in performing their role. The evaluation criteria we used to evaluate public councils in Kazakhstan are set out in Table 2.

Representativeness and independence. The composition of public councils is such that the state agencies for which they have oversight advisory responsibilities are also represented on each public council. Even though representation from public bodies provides only one-third of their members, they possess detailed knowledge of how public administration works in Kazakhstan and can, if they are so minded, use this to thwart the extent to which state agencies are held to account. Moreover, the selection of civil society members, although technically emerging from a 'competition' involving NGOs and citizens (Article 9 of the Law on Public Councils), must be approved by the head of the state body it will scrutinize. Our research found evidence that a number of those representing civil society were retired public officials from the same organization which the

Table 2. Rowe and Frewer's evaluation framework.

\begin{tabular}{|c|c|}
\hline Criteria & Definition \\
\hline \multicolumn{2}{|l|}{ Acceptance criteria } \\
\hline Representativeness & $\begin{array}{l}\text { The public involved in the exercise should comprise a broadly representative sample of the } \\
\text { population affected by the policy decision. }\end{array}$ \\
\hline Independence & The participation exercise should be conducted in an independent (unbiased) way. \\
\hline Early involvement & $\begin{array}{l}\text { The participants in the exercise should be involved as early as possible in the process, as soon } \\
\text { as societal values become important to the development of policy. }\end{array}$ \\
\hline Influence & The outcome of the procedure should have a genuine impact on policy. \\
\hline Transparency & $\begin{array}{l}\text { The process should be transparent so that the relevant/affected population can see what is } \\
\text { going on and how decisions are made. }\end{array}$ \\
\hline \multicolumn{2}{|r|}{ 9om } \\
\hline Resource accessibility & Participants should have access to the appropriate resources to enable them to fulfil their brief. \\
\hline Task definition & The nature and scope of the participation exercise should be clearly defined. \\
\hline $\begin{array}{l}\text { Structured decision- } \\
\text { making }\end{array}$ & $\begin{array}{l}\text { The participation exercise should use appropriate mechanisms for structuring/displaying the } \\
\text { decision-making process. }\end{array}$ \\
\hline Cost-effectiveness & $\begin{array}{l}\text { The process should be cost-effective from the point of view of the sponsors (for example, in } \\
\text { the case of proportionality of response). }\end{array}$ \\
\hline
\end{tabular}


public councils were tasked with holding to account. As the public council chair of the Ministry of Internal Affairs put it:

I'm not sure that we need one-third of the council represented by civil servants. They are actually using their authority and status to put pressure on the other members. They participate just to defend themselves and to have a constructive dialogue and hear some useful information for them.

Some public councils reported abuse of their independence, in that state agencies perceived them as a vehicle to diffuse controversial public policy issues. One example given was the current crisis over pension funding in Kazakhstan, which has been a public-sector debacle. ${ }^{3}$ The government has now established a public council to deal with this crisis. Such a move constitutes an abuse of the intended purpose of public councils because in this case the council is being used to divest government of its responsibilities and avoid future political risks. As importantly, it creates ambiguity in the minds of the public as to the role of public councils. The public council chair of the Ministry of Finance pointed out:

Each state body is different, has its own rules, traditions, and corporate ethics. The corporate ethics of the Ministry of Finance is, they think they are the smartest, they never listen to what we say, they always try to find reasons to decline any recommendations. And talking about independence, we cannot even control what information will be put on our page in the ministry's website. The persons responsible for what goes on the site are IT specialists. None of the representatives of the public council have access to the site. There is no possibility of discussing what materials are published on the website.

Task definition, early involvement and structured decision-making. One of the operational difficulties that public councils reported was the breadth of their mandate. They have been charged with multiple tasks and given little guidance on priorities. As a consequence, many have reacted in an ad hoc way, and their agendas have been driven by the demands of state bodies, which have crowded out opportunities to complete tasks of more immediate interest to their constituent members. As a public council member of the Ministry of Education and Science put it: 'Many members of public councils do not fully understand their functions and purposes, and don't realize their full potential.' One example of this is that public councils are often used by ministries as a consultative and advisory forum for draft legislation. The governance system in Kazakhstan has a significant legal basis, and hence public councils, whose members will lack training in this regard, become immersed in dense and technical legal documents with a 10-day turnaround period. If no response is forthcoming, then the ministry assumes the council's endorsement of the draft law. Ministries spotted this potential use of public councils very early and jumped in to fill their agendas, and as a consequence, limit their role to scrutinizing dense legal documents. The public council chair of the Agency of Civil Service Affairs and Anti-Corruption stated:

When I became chair of the public council I noticed that there were efforts and attempts to turn our activities into legal regulatory work. ... Instead we should be conducting public hearings.... It is necessary to hear the voices of the citizens, not government officials. We know what the officials think, we have to help society to be heard.

In addition, the Ministry of Religion and Civil Society Affairs, with overarching responsibility for public councils, has reacted to a recommendation from the $\operatorname{OECD}(2017,28)$, which 
pointed out: 'The law does not provide specific standards for the way public councils are formed and perform their duties.' The OECD therefore recommended that the government 'develop clear and simple procedures and guidelines for both public servants and citizens'. Despite the best intentions of this recommendation, it has provide a licence for bureaucratic indulgence on the part of the ministry, and attention has shifted from the potential outcomes of public councils to a preoccupation with process (selection, voting, operating procedures, etc.). This is not to devalue the importance of process, but in a system which has so far been largely stage-managed by the bodies which were to be held to account, attention to standards and procedures may well deflect from their primary scrutiny goal. In short, ministries have set the policy agenda of public councils to one of legislative consultation and procedural issues, and displaced potential opportunities for representing the voice of citizens, their key objective. As a result, public councils are unclear about their primary role and expectations, which seems to have moved some way from their original purpose, to express the views of civil society on matters of concern to Kazakh citizens - a clear example of mission drift. Public councils' potential for public monitoring and citizen engagement has been stymied and displaced, not helped by the lack of skills and knowledge on how best to perform these tasks.

The head of an NGO also called for a move away from the intensity of examining and commenting on legal documents. Instead, she argued:

I think we are missing one very effective tool in our work- public monitoring. We are not currently controlling the finances or the activities of the public body or local administration. If we did, we could start asking questions of various responsible bodies. It is a very useful tool, I believe.

Transparency and influence. State partners significantly condition the transparency of public councils. Councils are totally reliant on information technology personnel in ministries to publish and disseminate their work. This makes the bodies, over which they have a scrutiny role, gatekeepers in terms of their transparency to the public. There are potential consequences in terms of public awareness of the work of public councils and the extent to which they can influence government decision-making. As the head of the public council of the Ministry of Finance put it:

We [the public council] did not have access to the website of the ministry for eight months to publish our reports. We were refused service entry passes to the offices of the ministry. The Ministry of Finance has its own long traditions, and nothing will change until we change the thinking of officials.

The Zertteu Research Institute conducted an analysis of the websites of all ministries in relation to disseminating the work of public councils. They found that many of the ministries reported public councils as working 'under the Ministry of ... ', indicative of a principal-agent relationship rather than councils performing scrutiny and accountability roles. In addition, their research highlighted limited opportunities for engagement between the ministries and the public but rather a one-way information dissemination platform - publication of public council minutes, agenda, reports, etc. The director of the institute pointed out:

Based on the analysis of websites it seems that the work of public councils is not transparent. Apart from a few active ones, the others don't publish any information on their websites and don't have social media accounts to describe their work. 
The Ministry of Religion and Civil Society, which has direct responsibility for public councils, reports 'many successes' in their short life span. Public council members representing the NGO sector were much less sanguine. Some civil society participants have questioned their ability to influence the work of state agencies. A representative from the public council of the Ministry for Investment and Development noted:

It is not common practice for the ministry to accept our recommendations. What if we find problems in the effectiveness of spending the public budget? The ministry won't disseminate this information. What therefore is the real mechanism by which public councils' recommendations can be impactful?

To date it would appear that public councils are 'allowed' to perform their role within boundaries which are circumscribed by the ministries. When they move beyond these limits, which can create some public discomfort and potential political embarrassment, then there are cases of members being expelled, although the message is one of voluntary exit.

There are however examples where public councils have been influential, most specifically when they become involved in public hearings. The head of the public council of the Astana City Akimat reported on the outcomes of public hearings on transportation in the city, a location known for serious traffic congestion and gridlock during peak travel times:

First of all, we carried out monitoring, then asked experts to make a special inspection of the whole transport system in Astana City, the flow of traffic, how traffic lights work, etc. In the capital city we have many problems, including the additional congestion associated with EXPO 2017 [a global energy event]. During the public hearing around 700 people were in the hall.... People raised problems and expressed their opinion, which were all recorded, and then incorporated in recommendations that the public council gave to the akimat. Several normative documents [regulations] in the area of management of passenger transport and roads were amended based on that. We believe it was a real success for us.

All concerned were grateful for the opportunity to engage afforded by the public council, something which challenges the myth of an inactive and apathetic Kazakhstan public. Similar positive comments were made about the Almaty City Akimat, which has been very proactive in generating new ideas through its public council. This builds on its already positive image of citizen engagement through social media channels (Facebook, mobile applications, blogs), regular public hearings, and strong networking opportunities with business and potential investors. The Ministries of Agriculture and Internal Affairs were singled out as being very supportive of public hearings and the commitment of senior officials to report to public councils. The public council of the Ministry of Internal Affairs, for example, highlighted an example of their success on complaints made against police officers and allied employees in the ministry. They investigated this issue and reported back to the minister. This resulted in hearing reports from directors of departments in the Ministry of Internal Affairs on how these complaints were being dealt with.

What these examples illustrate however is that impact tends to be personality-dependent. In the cases of Astana and Almaty, both akims, or heads of the local government body (Iset Isekeshev and Baurzhan Baibek, respectively), are Western-educated Bolashak alumni who have imported public management thinking into their jobs. ${ }^{4}$ They value a client-oriented approach to the provision of public services and see the benefit of 
public councils as a mechanism to make this happen. While it is clearly useful to have such role models, this good practice needs to permeate the wider system of public councils in Kazakhstan. Without this, councils will be assimilated into existing bureaucratic mindsets and disproportionately influenced by the public officials who constitute one-third of their membership. Given their reliance on this sector for their expertise and resources (IT and administrative support, meeting venues, etc.), there is a real danger that public councils will be (ab)used by state agencies for their own ends.

Resource availability and cost-effectiveness. Public councils have no dedicated budget and rely on services and support from the state bodies they oversee. This dependency compromises their autonomy. Public council members perform their work on a voluntary basis and pay for expenses incurred in the course of their duties out of their own personal resources. This limits the work they can do and opportunities for innovative practice in engaging with and representing the views of the public. There has been little training and almost no professional development. The members of councils who are bogged down in the scrutiny of draft legislation are often lay people with no legal training or competencies in this field. Opportunities for sharing good practice, learning from other jurisdictions within and beyond Kazakhstan, are limited to their own resources. This is a significant limitation of the potential for public councils. Voluntary effort and the good will of civil society participants will dissipate unless there is financial support for their work, or at the very least payment for expenses incurred in the performance of their duties. Moreover, lack of financial support from the state is another way the potential of public councils can be thwarted. Yet it is clear that there is an appetite for professional development and learning amongst council members. A small example is that the workshops organized for this research attracted interest from a host of potential council participants, and numbers had to be limited. The narrative between public council members was rich, critically reflective, and keen to become involved in a constructive way in the job they had committed themselves to doing. There was a patent demand and obvious need for professional development. This issue of lack of resources was summarized by the public council chair of the Ministry of Internal Affairs:

One of the biggest problems for us is the absence of an officially allocated budget for running our everyday activities, as well as for trips that are required for field analysis and meeting people in the regions. In our work we need to talk with people, to see conditions in prisons for example, in order to respond to some complaints about bad conditions, which we have received. But we lack the funds for that. We are forced to find other opportunities, like using projects of international organizations, when they invite us to regions to participate in their workshops and discussions, we combine such trips to solve some of our tasks for public council activities.

From the qualitative data gathered on public councils we can locate their role as potentially one where communities, represented by civil society, could 'co-produce', using the Loeffler and Martin (2016) typology. If they prove effective this would represent the highest level of interaction between government and its citizens and the most extensive breadth of engagement, with annual reports from ministers and akims as the lowest level of interaction and engagement. In Table 3 we populate Loeffler and Martin's typology for Kazakhstan. 
Table 3. Citizen engagement in Kazakhstan, adapting Loeffler and Martin's framework to Kazakhstan.

\begin{tabular}{|c|c|c|c|c|}
\hline & & Low & Level of interaction & High \\
\hline & & Information & Consultation & Co-production \\
\hline [High] & Communities & Social media postings & Ministers' and akims' blogs & $\begin{array}{l}\text { Public councils } \\
\text { (potential) }\end{array}$ \\
\hline $\begin{array}{l}\text { Breadth of } \\
\text { engagement }\end{array}$ & Citizens & Government websites & $\begin{array}{l}\text { Open Government portal, Nur } \\
\text { Otan public reception }\end{array}$ & $\begin{array}{l}\text { Government for } \\
\text { Citizens initiative }\end{array}$ \\
\hline [Low] & Customers & $\begin{array}{l}\text { Annual reports of } \\
\text { ministers and akims }\end{array}$ & $\begin{array}{l}\text { Ministry-commissioned research } \\
\text { on public service users }\end{array}$ & $\begin{array}{l}\text { E-government } \\
\text { services }\end{array}$ \\
\hline
\end{tabular}

\section{Discussion and conclusions}

Even though public councils in Kazakhstan are still in the formative stages of development, a number of early conclusions can be drawn. The role of councils is much too broad, and as a result they have tended to operate at a very general level or been significantly (ab)used by ministries for their own purposes. One key role councils could play is to see themselves as guardians of those public services which most affect the well-being of Kazakh citizens (health, education, social welfare, pensions, etc.). There is also a need to make public councils truly independent of the organizations for which they exercise an advisory and consultative role, including the endorsement of the composition of public councils by oversight bodies which they are scrutinizing. There can be both the perception and the reality that state agencies are gatekeeping the composition of public councils. This will do little to reduce the public's distrust of the state and strengthen the concept of citizenship. Currently public councils suffer from a weak NGO infrastructure, which allows state bodies to place retired public officials as civil society 'representatives'. This is implicit manipulation of the role played by public councils.

There appears to be an appetite for public hearings as an overt expression of issues of concern to the citizens of Kazakhstan. The growing popularity of blogging and critical social commentary on the state's operations is testament to this trend. That said, recent research on blogging in the aftermath of a violent conflict in Zhanaozen in Kazakhstan in 2011 found that the State was able to reinforce its official version of events using social media despite an alternative discourse highly critical of the government's actions (Lewis 2016). Public councils could be subject to the same type of regulatory capture. They are part of the broader civil society space fighting for recognition and acceptance, whether in the form of service providers to government and/or advocates of social change. The role played by civil society in Kyrgyzstan, for example, offers an example where they opposed President Atambayev's attempts to amend the constitution and reassert a more autocratic regime. If public councils in Kazakhstan are to effectively embrace this kind of challenge and advocacy role, they need to improve their capacity to mobilize, synthesize and articulate these concerns back to state agencies in a way which results in demonstrable public policy changes.

This links to the need for public councils to be resourced in order to do their work, and for training of their members. To expect a council to be an effective advisory and consultative body without, at a minimum, resources for legitimate expenses and training costs is unrealistic. This finding simply reaffirms Brady, Verba, and Schlozman's (1995) seminal study showing that people will not be politically active if there is a deficiency in resources (time, money and civic skills). Voluntary efforts on the part of council members will quickly 
dissipate if they see that their work has little effect. Importantly, Starr, Engvall, and Cornell $(2016,54)$ have argued that Kazakhstan needs to 'transform fundamentally what it means to be a civil servant and the way services and goods are exchanged between public officials and citizens'. To do this, they assert, demands much more than adopting policies drawn from successful international experience. Most such approaches, they suggest, 'neglect the need to generate demand for change from inside public bodies themselves'.

In summary, the evidence from this formative evaluation is mixed. There is an appetite for ways for the citizens of Kazakhstan to express their opinion on matters of concern, and public councils could provide that mechanism. Equally, there is reluctance on the part of state agencies to allow this, because they are concerned that strong public opinions could escalate to political instability. Where public councils have been allowed to use their most effective tools, public hearings and monitoring, they could mount strong advocacy campaigns. But the effectiveness of these is still too personality-dependent, which makes them unsustainable. Some ministries have reverted to type and attempted successfully to control the agenda of public councils by transforming their role to scrutiny of legal documents. The more enlightened officials have seen the potential of public councils. Devoid of funding and with information and publicity entirely in the hands of the agencies over which they have a scrutiny role, it is questionable how long public councils can sustain their current level of voluntary commitment and public profile. What began as a well-conceived strategy for citizen engagement may turn out to be little more than an exercise in political tokenism.

\section{Notes}

1. The 20 countries in the meta-analysis involved a sub-sample of 83 single-country case studies which spanned: tier one, rich Northern countries (9); tier two, mostly middle-income democracies in the South (50); and, tier three, countries which are considered fragile states (24).

2. The Freedom House Report 2017 lists the following indices of rights and freedom in Central Asia as follows: [Kazakhstan: 22 (not free); Kyrgyzstan: 37 (party free); Tajikistan: 11 (not free); Uzbekistan: 3 (not free); Turkmenistan: 3 (not free)].

3. In 1998 Kazakhstan introduced a funded pension scheme replacing the former Soviet Union's system. Following the financial crisis in 2008 , its performance significantly deteriorated, which raised questions about the ability of pension funds to provide adequate benefits in the future. The Single Accumulated Pension Fund was set up in 2013 as the only pension fund in Kazakhstan after all private funds were forcibly nationalized. Controversy has recently surrounded the fund's acquisitions. In December 2016 two top fund managers and two entrepreneurs operating in the natural resources sector were arrested on suspicion of misusing pension fund assets (Zhandildin 2015).

4. The Kazakhstan government has provided generous funding to send their most talented students to the best universities in the world through the Bolashak programme (the name means 'the future').

\section{Disclosure statement}

No potential conflict of interest was reported by the authors.

\section{Funding}

The authors acknowledge and thank Gaukhar Maikenova for her assistance with the primary fieldwork and acknowledge travel cost funding from the British Academy (Grant PM150036). 


\section{References}

Amagoh, F. 2011. "New Public Management and Health Reform in Kazakhstan." International Journal of Public Administration 34 (9): 567-578. doi:10.1080/01900692.2011.589095

Arnstein, S. 1969. "The Ladder of Citizen Participation." Journal of the American Institute of Planners 35 (4): 216-224. doi:10.1080/01944366908977225

Babajanian, B., S. Freizer, and D. Stevens. 2005. "Introduction: Civil Society in Central Asia and the Caucasus." Central Asian Survey 24 (3): 209-224. doi:10.1080/02634930500310287

Bertelsmann Transformation Index (BTI). 2016. Report, Kazakhstan Country Report. http://www.btiproject.org.

Bhuiyan, S. H., and F. Amagoh. 2011. "Public Sector Reform in Kazakhstan: Issues and Perspectives." International Journal of Public Sector Management 24 (3): 227-249. doi:10.1108/ 09513551111121356

Brady, H., S. Verba, and K. Schlozman. 1995. "Beyond SES: A Resource Model of Political Participation." American Political Science Review 89 (02): 271-294. doi:10.2307/2082425

Buxton, C. 2009. "NGO Networks in Central Asia and Global Civil Society: Potentials and Limitations." Central Asian Survey 28 (1): 43-58. doi:10.1080/02634930902775129

Cavatorta, F., and V. Durac. 2011. Civil Society and Democratization in the Arab World: The Dynamics of Activitism. London: Routledge.

Charman, K., and R. Assangaziyev. 2015. "Civil Service and Public Satisfaction: From Functions to Services - The Case of Kazakhstan." In Civil Society and Politics in Central Asia, edited by C. Ziegler, 169-196. Lexington: University Press of Kentucky.

Daucé, F. 2014. "The Government and Human Rights Groups in Russia: Civilized Oppression?" Journal of Civil Society 10 (3): 239-254. doi:10.1080/17448689.2014.941087

Ekman, J., and E. Amnå. 2012. "Political Participation and Civic Engagement: Towards a New Typology." Human Affairs 22 (3): 283-300. doi:10.2478/s13374-012-0024-1

Emrich-Bakenova, S. 2009. "Trajectory of Civil Service Development in Kazakhstan: Nexus of Politics and Administration." Governance 22 (4): 717-745. doi:10.1111/j.1468-0491.2009.01460.x

Freedom House Report. 2017. Nations in Transit: Kazakhstan Country Profile. https://freedomhouse. org/report/nations-transit/2017/kazakhstan.

Fung, A. 2015. "Putting the Public Back Into Governance: The Challenges of Citizen Participation and its Future." Public Administration Review 75 (4): 513-522. doi:10.1111/puar.12361

Gaventa, J., and G. Barrett. 2010. So What Difference Does it Make? Mapping the Outcomes of Citizen Engagement. IDS Working Paper 347 University of Sussex Brighton Institute of Development Studies.

Holmes, B. 2011. Citizens' Engagement in Policy Making and the Design of Public Services. Canberra, Australia: Parliament of Australia: Department of Parliamentary Services.

Janenova, S., and P. S. Kim. 2016. "Innovating Public Service Delivery in Transitional Countries: The Case of One Stop Shops in Kazakhstan." International Journal of Public Administration 39 (4): 323-333. doi:10.1080/01900692.2015.1064445

Kabdiyeva, A. 2015. "Development of NGOs in Kazakhstan." European Journal of Business and Social Sciences 4 (2): 159-169.

Kasymova, J. 2017. "Understanding the Challenges and Sustainability of Citizen Engagement in the Budgeting Processes of Developing Countries." Administration and Society 49 (3): 374-393. doi:10. $1177 / 0095399714558713$

Kazkenov, R., and C. Ziegler. 2015. "Civil Society in a Period of Transition: The Perspective From the State." In Civil Society and Politics in Central Asia, edited by C. Ziegler, 197-222. Lexington: University Press of Kentucky.

Knox, C. 2008. "Kazakhstan: Modernizing Government in the Context of Political Inertia." International Review of Administrative Sciences 74 (3): 477-496. doi:10.1177/0020852308095314

Knox, C., and S. Yessimova. 2015. "State-Society Relations: Non-Government Organisations in Kazakhstan." Journal of Civil Society 11 (3): 300-316. doi:10.1080/17448689.2015.1058322

Lewis, D. 2016. "Blogging Zhanaozen: Hegemonic Discourse and Authoritarian Resilience in Kazakhstan." Central Asian Survey 35 (3): 421-438. doi:10.1080/02634937.2016.1161902 
Lillis, J. 2017. Kazakhstan Country Report. Washington, D.C.: Freedom House.

Loeffler, E., and S. Martin. 2016. "Citizen Engagement." In Public Management and Governance, edited by T. Bovaird and E. Loeffler, 3rd ed., 301-318. London: Routledge.

Manning, N. 2001. "The Legacy of the New Public Management in Developing Countries." International Review of Administrative Sciences 67 (2): 297-312. doi:10.1177/0020852301672009

Michels, A. 2011. "Innovations in Democratic Governance: how Does Citizen Participation Contribute to a Better Democracy?" International Review of Administrative Sciences 77 (2): 275-293. doi:10. $1177 / 0020852311399851$

Monobayeva, A., and C. Howard. 2015. "Are Post-Soviet Republics Ready for the new Public Management? The Case of Educational Modernization in Kazakhstan." International Journal of Public Sector Management 28 (2): 150-164. doi:10.1108/IJPSM-08-2014-0102

Mouffe, C. 1992. "Democratic Citizenship and the Political Community." In Dimensions of Radical Democracy: Pluralism, Citizenship, Community, edited by C. Mouffe, 225-239. London: Verso.

Nezhina, T. G., and A. R. Ibrayeva. 2013. "Explaining the Role of Culture and Traditions in Functioning of Civil Society Organizations in Kazakhstan." Voluntas: International Journal of Voluntary and Nonprofit Organizations 24 (2): 335-358. doi:10.1007/s11266-011-9256-7

OECD (Organization for Economic Cooperation and Development). 2015. Multi-Dimensional Review of Kazakhstan: Volume 1 - Initial Assessment. Paris: OECD Publishing.

OECD (Organization for Economic Cooperation and Development). 2017. Towards Effective Open Government Reforms in Kazakhstan. Paris: OECD Publishing.

Rivetti, P., and F. Cavatorta. 2013. "'The Importance of Being Civil Society': Student Politics and the Reformist Movement in Khatami's Iran." Middle Eastern Studies 49 (4): 645-660. doi:10.1080/ 00263206.2013.798311

Rowe, G., and L. Frewer. 2000. "Public Participation Methods: A Framework for Evaluation." Science, Technology, \& Human Values 25 (1): 3-29. doi:10.1177/016224390002500101

Sen, A. 1999. Development as Freedom. Oxford: Oxford University Press.

Soltys, D. 2014. "Challenges to the Institutionalisation of Environmental NGOs in Kazakhstan's Corporatist Policy Arena." Journal of Contemporary Asia 44 (2): 342-362. doi:10.1080/00472336. 2013.848314

Starr, F., J. Engvall, and S. Cornell. 2016. Kazakhstan 2041: The Next Twenty-Five Years. Washington: Johns Hopkins University, Central Asia-Caucasus Institute and Silk Road Studies Program.

Thompson, L., and C. Tapscott, eds. 2010. Citizenship and Social Movements: Perspectives From the Global South. London and New York: Zed.

Tritter, J., and A. McCallum. 2006. "The Snakes and Ladders of User Involvement: Moving Beyond Arnstein." Health Policy 76 (2): 156-168. doi:10.1016/j.healthpol.2005.05.008

UNDP. 2016a. Citizen Engagement in Public Service Delivery - The Critical Role of Public Officials. Singapore: UNDP Global Centre for Public Services.

UNDP. 2016b. United Nations Development Programme Report 2016. http://hdr.undp.org/en/ composite/HDI.

World Bank. 2016. Kazakhstan: A Long Road to Recovery. http://www.worldbank.org/en/country/ kazakhstan/publication/economic-update-summer-2016.

Zhandildin, M. 2015. "Pension System Reform in Emerging Countries: The Case of Kazakhstan." Global Journal of Emerging Market Economies 7 (1): 65-88. doi:10.1177/0974910114556939

Ziegler, C. 2010. "Civil Society, Political Stability, and State Power in Central Asia: Cooperation and Contestation." Democratization 17 (5): 795-825. doi:10.1080/13510347.2010.501172

Ziegler, C. 2015. "Introduction." In Civil Society and Politics in Central Asia, edited by C. Ziegler, 1-20. Lexington: University Press of Kentucky.

Ziegler, C. 2016. "Great Powers, Civil Society and Authoritarian Diffusion in Central Asia." Central Asian Survey 35 (4): 549-569. doi:10.1080/02634937.2016.1228608 